\title{
Penggunaan Campuran Magnesium Sulfat dan Arang Tempurung Kelapa Sebagai Upaya Perbaikan Resistansi Pentanahan \\ Elektroda Jenis Batang
}

Dasrinal Tessal ${ }^{1}$, Widiansyah Ardi ${ }^{1}$, dan Nehru ${ }^{1}$

${ }^{1}$ Program Studi Teknik Elektro, Fakultas Sains dan Teknologi, Universitas Jambi

Email: dasrinaltessal@unja.ac.id, widiansyah124@gmail.com,nehru@unja.ac.id

\section{Info Artikel}

Diterima: 19 Januari 2021

Disetujui: 26 Januari 2021

Dipublikasikan: 29 Januari 2021

\section{Alamat Korespondensi: \\ dasrinaltessal@unja.ac.id \\ Copyright (C) 2021 Jurnal \\ Engineering}

This work is licensed under the Creative Commons Attribution International License (CC BY 4.0).

\begin{abstract}
Abstrak
Usaha dalam perbaikan tahanan pentanahan dapat dilakukan dengan berbagai cara. Salah satu caranya adalah dengan memakai magnesium sulfat dan arang tempurung kelapa. Kedua zat tersebut digunakan pada elektroda pentanahan berjenis tembaga dan pipa galvanis masing-masing tertanam 1 meter dari permukaan tanah. Zat kemudian ditambahkan pada lubang berdiameter $12 \mathrm{~cm}$ dengan elektroda atau pipa sebagai titik tengahnya. Tanah yang dipakai dalam penelitian berjenis tanah liat. Pengukuran nilai tahanan elektroda menggunakan metode 3 titik. Pengamatan dilakukan selama 7 hari dan dilakukan pada jam 9.00, 11.00, 13.00 dan 15.00. Nilai pengukuran tahanan pada elektroda tembaga tanpa perlakuan rata-rata bernilai $107 \mathrm{ohm}$ dan dengan penambahan arang tempurung kelapa ,magnesium sulfat, , dan campuran keduanya masing-masingnya adalah $84,1 \Omega, 62,9 \Omega$ dan 79,3 $\Omega$. Pada pipa galvanis nilai tahanan rata-rata awal sebelum penambahan zat sebesar $84,1 \Omega$ setelah penambahan arang tempurung kelapa,magnesium sulfat dan campuran keduanya masing-masing bernilai $60,1 \Omega, 38,8 \Omega$, dan $51,3 \Omega$.
\end{abstract}

Kata kunci: Arang Tempurung Kelapa; Elektroda Tembaga; Magnesium Sulfat; Pipa Galvanis

\section{Pendahuluan}

Penerapan sistem pentanahan sama tuanya dengan perkembangan sistem tenaga listrik. Sistem pentanahan merupakan sistem pengamanan terhadap peralatan listrik atau jaringan terhadap petir dan gangguan hubung singkat serta juga melindungi manusia yang ada disekitarnya dari sengatan listrik. Pada dasarnya sistem pentanahan adalah peralatan yang terdiri dari elektroda pentanahan yang dibutuhkan bersama hantaran pentanahan. Elektroda pentanahan dapat berupa batang yang ditanam tegak lurus atau ditanam sejajar permukaan tanah dan berupa lempeng atau plat yang kesemuanya ini dirancang untuk memperkecil tahanan pentanahan. Untuk hal tersebut terlebih dahulu harus ditentukan bahan maupun sifat 
elektrodanya, yang terutama harus mempunyai konduktifikasi yang tinggi serta resistivitas yang rendah, agar arus yang mengalir cepat ke dalam tanah (Garniwa, 2003).

Nilai resistansi pentanahan dipengaruhi beberapa faktor yaitu, jenis elektroda, suhu, kelembaban, jenis tanah, zat kimia yang terkandung dan temperatur tanah. Nilai resistansi pentanahan digunakan untuk memenuhi syarat suatu instalasi, karena sangat mempengaruhi cepat lambatnya penyaluran energi listrik jika terjadi hubung singkat. Berikut nilai tahanan jenis tanah berdasarkan jenis tanah, tanah rawa $30 \Omega \mathrm{m}$, tanah liat dan ladang $100 \Omega \mathrm{m}$, pasir basah $200 \Omega \mathrm{m}$, kerikil basah $500 \Omega \mathrm{m}$, pasir dan kerikil kering $1000 \Omega \mathrm{m}$, tanah berbatu $3000 \Omega \mathrm{m}$ (PUIL, 2000).

Pengurangan nilai tahanan pentanahan dapat dilakukan dengan penambahan zat bantu seperti garam (Sunawar, 2013). Dari penelitian tersebut maka perlu dilakukan penelitian tentang zat aditif lain yang dapat digunakan dalam menurunkan tahanan tanah yakni Magnesium Sulfat dan Arang Tempurung Kelapa. Magnesium Sulfat dipakai dengan alasan yang dapat menetralisir kejenuhan elektroda dan dapat menurunkan tingkat keasaman tanah sehingga membantu proses perlambatan korosi yang terjadi pada elektroda yang penggunaannya sering dicampur dengan gypsum(Yuniarti, 2017). Sedangkan arang Tempurung Kelapa memiliki nilai resistivitas yang lebih rendah dari tanah serta memiliki struktur pori yang lebih besar sehingga dapat menyerap air lebih banyak dan memiliki sifat konduktif (Lucky Dedi ,2013).

\section{Metode Penelitian}

Metode penelitian yang digunakan adalah metode eksperimen dimana pengujian yang dilakukan pengaruh suatu variabel terhadap variabel lainnya, pada penelitian ini eksperimen yang dilakukan adalah pengaruh yang timbul pada saat pengukuran nilai tahanan tanah pada tanah liat sebelum dan sesudah dilakukannya penambahan magnesium sulfat dan arang tempurung kelapa atau campuran dari magnesium sulfat dan arang tempurung kelapa

a) Waktu dan Tempat Penelitian

Penelitian dilakukan di Universitas Jambi Kecamatan Muaro jambi Pondok Meja, pada bulan September 2020 hingga Oktober 2020, waktu pengukuran dilakukan selama 7 hari dari waktu pengukuran 09.00 WIB , 11.00 WIB, 13.00 WIB dan 15.00 WIB.

b) Prosedur Penelitian

Diagram alir penelitian dilakukan berdasarkan diagram alir pada Gambar 1. Setelah lubang observasi dibuat sebanyak empat buah (tanpa penambahan, dengan penambahan arang, dengan penambahan campuran arang dan magnesium sulfat dengan perbandingan 1:1). Bahan aditif ini dimasukan ke dalam lubang elektroda dengan jari-jari lubang $6 \mathrm{~cm}$ dengan kedalaman yang sama dengan panjang konduktor yang ditanamkan. Seperti yang terlihat pada Gambar 2. 


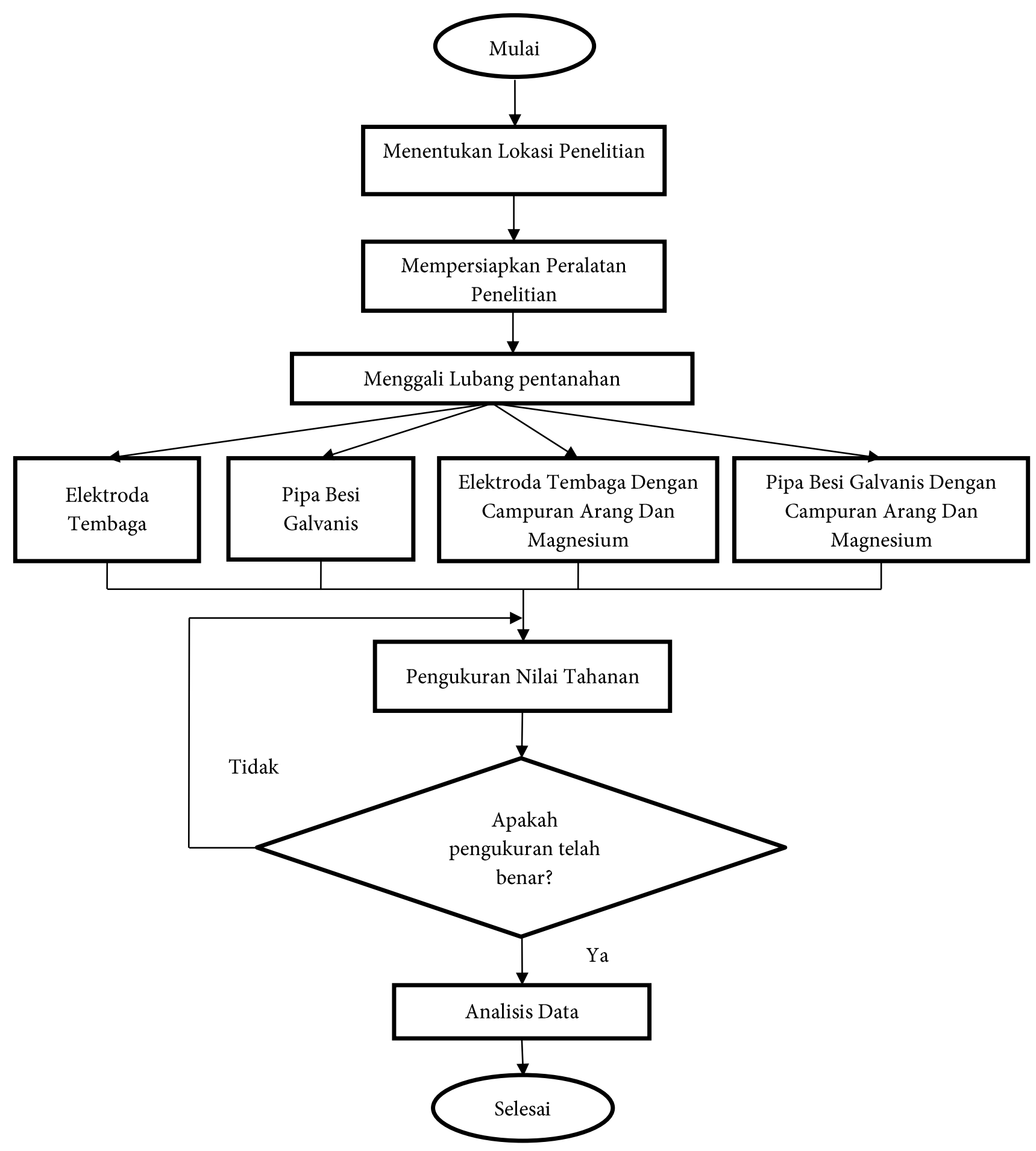

Gambar 1. Diagram Alir Penelitian 


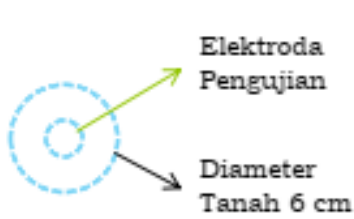

Tampak Depan

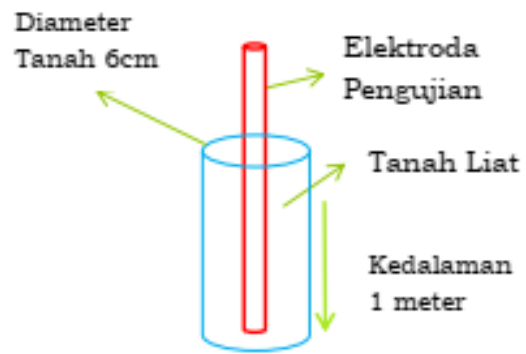

Gambar 2. Lubang Penanaman Elektroda

Jumlah berat bahan aditif yang dipakai pada jenis elektroda tembaga sebanyak 8,5 kg Magnesium Sulfat dan 8,5 kg arang tempurung Arang. Pipa Galvanis membutuhkan 7,5 kg Magnesium Sulfat dan 7,5 arang tempurung kelapa. Campuran keduanya membutuhkan 4,5 kg Magnesium Sulfat dan 4,5 $\mathrm{kg}$ arang tempurung kelapa.

c) Data, Instrumen, dan Teknik Pengumpulan Data

1. Data

Data yang direkam adalah nilai tahanan pada waktu yang telah ditentukan selama 7 hari diukur dengan menggunakan metode 3 titik. Data nilai tahanan elektroda pentanahan dirangkum dalam Microsoft Excel dan Nilai pengukuran ditampilkan rata-ratanya saja dalam bentuk Tabel dan grafik batang untuk melihat perbandingannya.

2. Instrumen

Pengukuran dilakukan dengan alat ukur tahanan tanah merk Kyoritsu seri 4015A dengan dua elektroda bantu. Alat bantu lainnya adalah linggis/tembilang untuk lobang. Meteran untuk mengukur kedalaman tanah dan diameter lubang. Timbangan untuk mengukur jumlah magnesium dan arang yang dipakai untuk mengisi lubang yang telah dibuat.

3. Teknik pengumpulan Data

Pengukuran menggunakan metode tiga titik yang ditampilkan pada Gambar 3

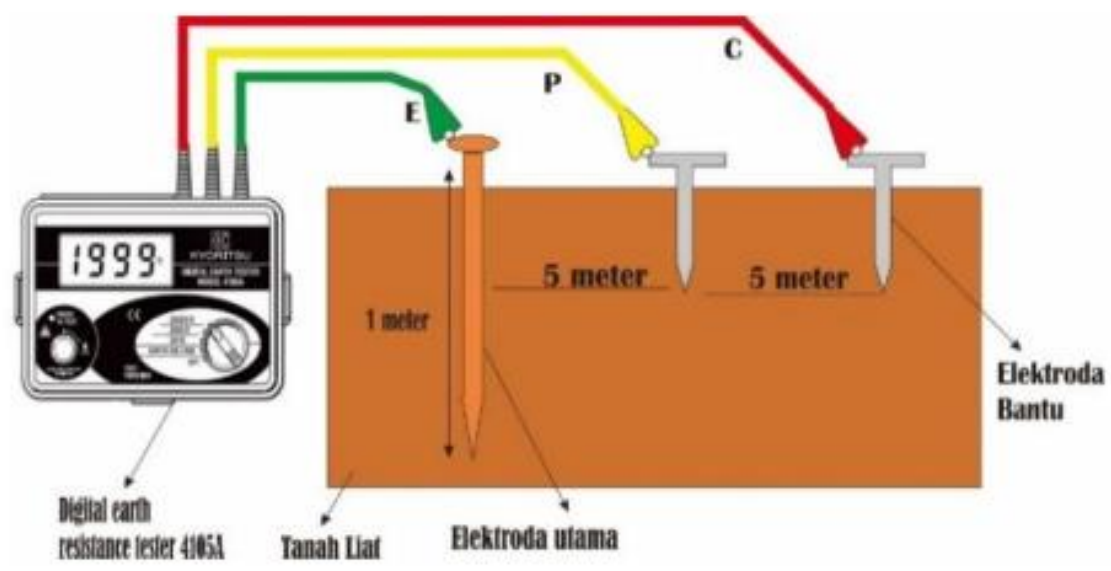

Gambar 3. Pengukuran Tahanan dengan Metode 3 titik pada elektroda tanpa penambahan zat aditif 


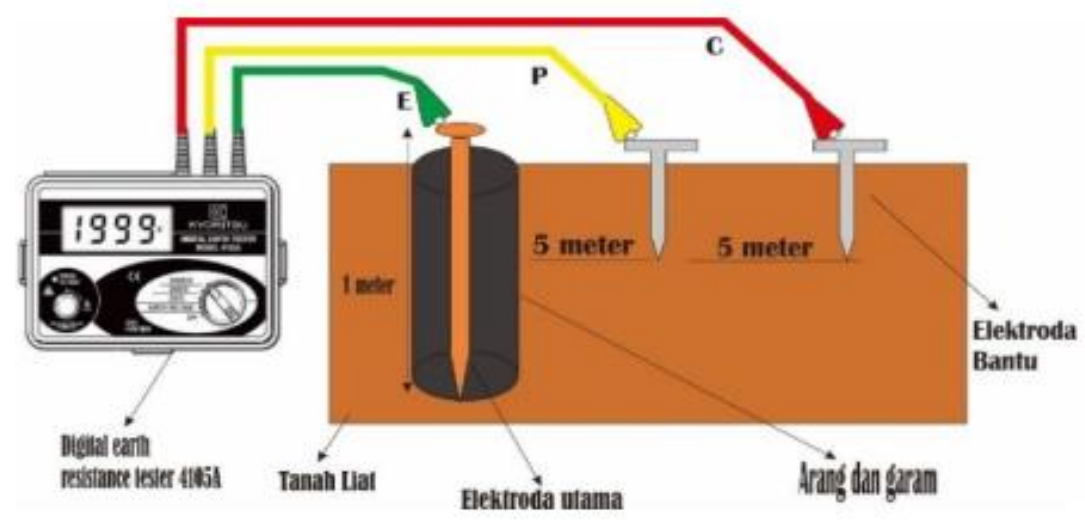

Gambar 4. Pengukuran Tahanan dengan Metode 3 titik pada elektroda dengan penambahan zat aditif

\section{Hasil Penelitian}

Data-data yang diambil yaitu pengukuran nilai tahanan pentanahan pada tanah liat, dan hasil pengukurannya sebagai berikut:

A. Hasil Pengukuran Nilai Tahanan Pentanahan Dengan Elektroda Tembaga Tunggal Dan Pipa Besi Galvanis Tunggal.

Tabel 1. Hasil pengukuran nilai rata-rata menggunakan elektroda tembaga sebelum ditambahkan Magnesium Sulfat dan arang

\begin{tabular}{cc}
\hline Hari & Elektroda Tembaga \\
\hline 1 & $111 \Omega$ \\
2 & $112 \Omega$ \\
3 & $116 \Omega$ \\
4 & $98,3 \Omega$ \\
5 & $110 \Omega$ \\
6 & $109 \Omega$ \\
7 & $97,5 \Omega$ \\
\hline
\end{tabular}

Tabel 2. Hasil pengukuran nilai rata-rata menggunakan pipa besi galvanis sebelum ditambahkan magnesium sulfat dan arang.

\begin{tabular}{cc}
\hline Hari & $\begin{array}{c}\text { Elektroda } \\
\text { Pipa Besi Galvanis }\end{array}$ \\
\hline 1 & $87,2 \Omega$ \\
2 & $86,1 \Omega$ \\
3 & $87,5 \Omega$ \\
4 & $77,6 \Omega$ \\
5 & $86,4 \Omega$ \\
6 & $87,8 \Omega$ \\
7 & $79,5 \Omega$ \\
\hline
\end{tabular}


Tabel 1 dan 2 diatas merupakan hasil rata-rata pengukuran nilai tahanan pentanahan dari hari ke 1 sampai ke 7 dengan menggunakan elektroda tembaga dan pipa besi galvanis berdiameter $25 \mathrm{~mm}$. Hari keempat nilai pentanahan lebih rendah dari hari lainnya disebabkan turunnya hujan sehingga kelembapan tanah menjadi lebih tinggi. Hal ini menjadi faktor berkurangnya tahanan pentahanan. Rata-rata nilai pentanahannya selama pengukuran 7 hari sebesar $107 \Omega$

\section{B. Hasil Pengukuran Nilai Tahanan Pentanahan Dengan Elektroda Tembaga Tunggal Dan Pipa Besi Galvanis Yang Telah Ditambah Arang Dan Magnesium Sulfat}

Tabel 3. Hasil Pengukuran Rata-Rata Pada Elektroda Tembaga Sesudah Ditambahkan Arang Dan Magnesium.

\begin{tabular}{cccc}
\hline & \multicolumn{3}{c}{ Elektroda tembaga } \\
\cline { 2 - 4 } Hari & Arang & Magnesium & Magnesium+arang \\
\hline 1 & $90,0 \Omega$ & $66,4 \Omega$ & $85,0 \Omega$ \\
2 & $89,2 \Omega$ & $64,6 \Omega$ & $81,3 \Omega$ \\
3 & $87,1 \Omega$ & $68,3 \Omega$ & $83,6 \Omega$ \\
4 & $75,2 \Omega$ & $56,7 \Omega$ & $72,2 \Omega$ \\
5 & $85,5 \Omega$ & $61,4 \Omega$ & $82,4 \Omega$ \\
6 & $88,3 \Omega$ & $66,8 \Omega$ & $79,1 \Omega$ \\
7 & $76,3 \Omega$ & $55,7 \Omega$ & $72,5 \Omega$ \\
\hline
\end{tabular}

Dari data pada Tabel 3 didapatkan hasil rata-rata nilai pentanahannya selama 7 hari untuk penambahan arang bernilai $62,9 \Omega$, penambahan magnesium didapatkan bernilai $84,1 \Omega$, dan campuran arang dan magnesium sebesar 79,3 $\Omega$. Dari pengukuran tersebut terjadi penurunan nilai tahanan tanah itu dimana :

a) Nilai tahanan pentanahan setelah ditambahkan magnesium sulfat mengalami penurunan sebesar $44,1 \Omega$ atau $41,2 \%$.

b) Nilai tahanan pentanahan setelah ditambahkan arang tempurung kelapa mengalami penurunan sebesar $22,9 \Omega$ atau $21,4 \%$.

c) Nilai tahanan pentanahan setelah ditambahkan campuran magnesium sulfat dan arang tempurung kelapa mengalami penurunan sebesar $27,7 \Omega$ atau $25,88 \%$.

Tabel 4. Hasil Pengukuran Rata-Rata Pada Pipa Galvanis Sesudah Ditambahkan Arang Dan Magnesium.

\begin{tabular}{cccc}
\hline & \multicolumn{3}{c}{ Pipa Galvanis } \\
\cline { 2 - 4 } Hari & Arang & Magnesium & Magnesium+ Arang \\
\hline 1 & $61,8 \Omega$ & $43,1 \Omega$ & $55,4 \Omega$ \\
2 & $64,2 \Omega$ & $41,6 \Omega$ & $53,5 \Omega$ \\
3 & $61,5 \Omega$ & $42,9 \Omega$ & $52,4 \Omega$ \\
4 & $55,7 \Omega$ & $29,7 \Omega$ & $41,8 \Omega$ \\
5 & $61,1 \Omega$ & $40,8 \Omega$ & $46,8 \Omega$ \\
6 & $62,6 \Omega$ & $41,4 \Omega$ & $49,0 \Omega$ \\
7 & $53,7 \Omega$ & $31,8 \Omega$ & $40,5 \Omega$ \\
\hline
\end{tabular}


Dari hasil pengukuran yang ditampilkan pada tabel 4 data pengukuran nilai tahanan tanah selama 7 hari dimana nilai tahanan paling rendah karena menggunakan elektroda pipa besi galvanis yang diameternya lebih besar dari pada elektroda tembaga sehingga sangat berpengaruh terhadap nilai tahanan yang terukur. Penambahan bahan berupa magnesium sulfat dan arang tempurung kelapa memberikan perubahan seperti dijelaskan dibawah ini:

a) Nilai tahanan setelah ditambahkan magnesium sulfat mengalami penurunan sebesar $45,2 \Omega$ atau 53,8\%.

b) Nilai tahanan setelah ditambahkan arang tempurung kelapa mengalami penurunan sebesar $23,9 \Omega$ atau $28,45 \%$

c) Nilai tahanan setelah ditambahkan campuran magnesium sulfat dan arang tempurung kelapa mengalami penurunan sebesar $32,7 \Omega$ atau $38,9 \%$.

\section{Pembahasan}

Berdasarkan dari pengukuran nilai tahanan yang tercatat di lapangan, perbandingan antara penggunaan elektroda tembaga dan pipa besi galvanis sebelum pemberian magnesium sulfat dan arang tempurung kelapa dapat ditampilkan pada grafik di Gambar 5.

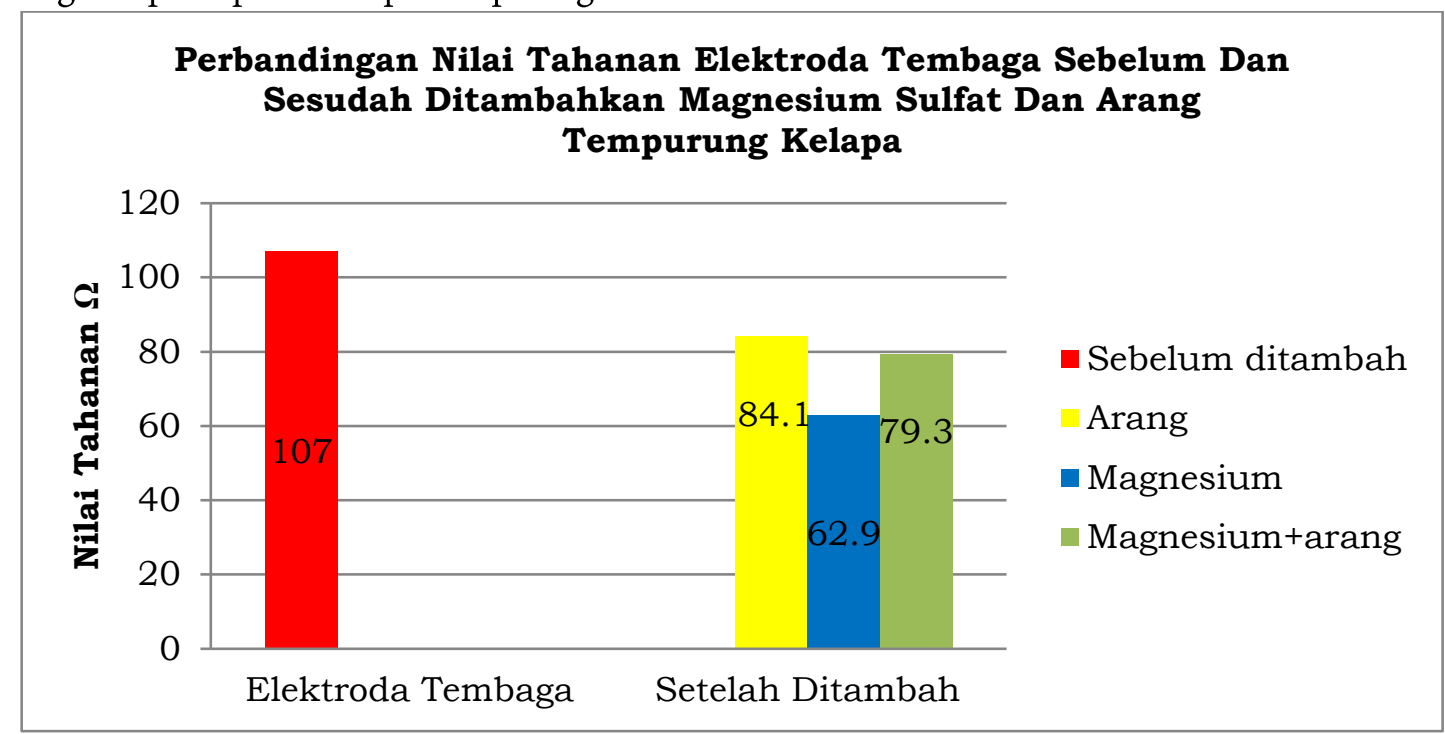

Gambar 5. Grafik perbandingan nilai Tahanan elektroda tembaga sebelum dan sesudah ditambahkan magnesium sulfat dan arang tempurung kelapa.

Pada Gambar 5 diatas, nilai rata-rata yang didapatkan dengan menggunakan elektroda tembaga dengan diameter elektroda tembaga berukuran $16 \mathrm{~mm}$, didapat nilai yang berbeda sebelum dan sesudah ditambah magnesium sulfat dan arang tempurung kelapa yang mana nilai tahanan tanah dengan elektroda tembaga lebih kecil setelah penambahan magnesium sulfat dan arang tempurung kelapa, dikarenakan dengan menggunakan arang tempurung kelapa dapat menyerap air dan membuat keadaan tanah disekitar elektroda pengujian menjadi tetap lembab dan menggunakan magnesium sulfat juga sangat baik untuk menurunkan nilai tahanan pentanahan karena magnesium sulfat bersifat garam anorganik dengan konduktivitas yang sangat baik, ketika dimasukkan kedalam tanah bersamaan elektroda pengujian akan membuat keadaan tanah mejadi tetap lembab dan juga bisa memperlambat korosi pada elektroda yang digunakan. Data yang didapatkan dengan menggunakan magnesium sulfat lebih baik ketimbang arang 
tempurung kelapa untuk menurunkan nilai tahanan pentanahan pada tanah liat menggunakan elektroda tembaga.

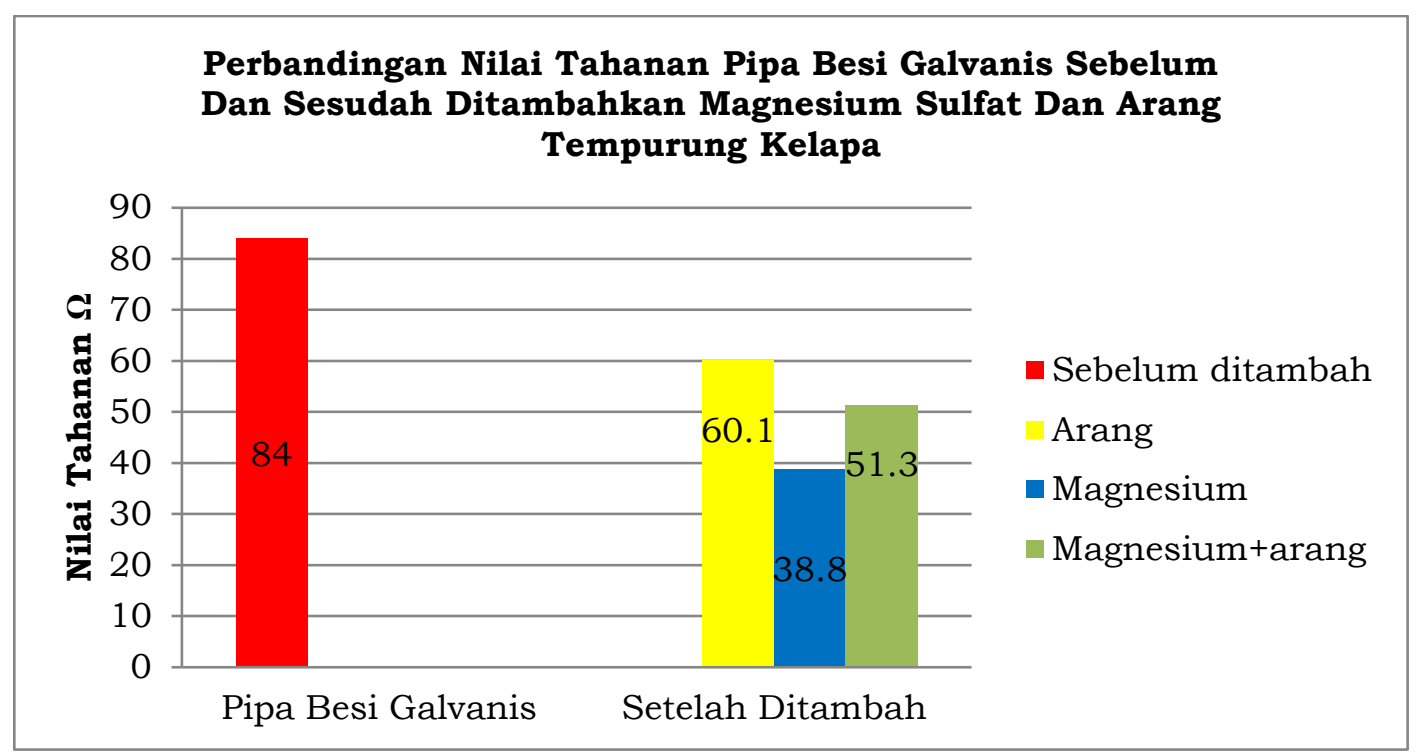

Gambar 6. Grafik perbandingan nilai Tahanan pipa besi galvanis sebelum dan sesudah ditambahkan magnesium sulfat dan arang tempurung kelapa.

Gambar 6 menampilkan perbandingan data pengukuran dengan menggunakan earth tester pada pipa galvanis tanpa penambahan zat aditif dan penambahan zat aditif nilai pengujian tahanan pentanahan setelah penambahan megnesium sulfat dan arang tempurung kelapa. Terlihat bahwasannya penggunaan elektroda berukuran $25 \mathrm{~mm}$, didapat nilai tahanan yang kecil dikarenakan daya sebar arus ketanah lebih luas dibandingkan dengan elektroda tembaga. Maka pemakaian pipa galvanis dalam sistem pentanahan akan memberikan perlindungan yang lebih baik dibandingkan dengan elektroda tembaga.

\section{Kesimpulan}

Pada penelitian ini menggunakan elektroda tembaga dan pipa besi galvanis dan didapatkan hasil pengukuran nilai tahanan tanah, yang mana nilai yang didapat menggunakan pipa besi galvanis lebih kecil dari pada tembaga dikarenakan luas penampang pipa besi galvanis lebih besar dari elektroda tembaga, yang mana luas permukaan batang elektroda yang besar sangat baik untuk menghantar arus gangguan ke tanah, dan setelah dilakukan penelitian penggunaan campuran magnesium sulfat dan arang tempurung kelapa bisa digunakan sebagai penurun nilai tahanan tanah dikarenakan arang bersifat higroskopis dan magnesium sulfat bersifat elektrolit dengan konduktivitas yang sangat baik.

\section{Daftar Pustaka}

[1] Garniwa, I. (2003). Jurusan Elektro FTUI. Dasar Perencanaan Instalasi Penangkal Petir.

[2] Ilahi, A. (2005). Universitas Lampung. Studi Sistem Pembumian batang Tunggal dengan Menganalisis Resistansi Jenis Tanah.

[3] PUIL. (2000). persyaratan umum instalasi listrik 2000 (puil 2000). jakarta: badan standardisasi nasional (bsn). 
[4] Sunawar, A. 2. (2013). Universitas Negeri Jakarta. Analisis Pengaruh dan Kadar Garam Terhadap Hambatan Jenis Tanah, Vol. 2 No.1.

[5] Aslimeri, d. (2008). Teknik Transmisi Tenaga Listrik Jilid 2 (Vol. 262). Jakarta: Depdiknas

[6] Salamena, V. (2018). Jurnal Simetrik. Pengaruh Kedalaman Elektroda Terhadap Pengukuran Tahanan Jenis Tanah,Pasir dan Air Laut di Pulau Ambon Dengan Konfigurasi Wenner Alfa. Jurnal Simetri,VOL.8, NO.1

[7] Yuniarti, Y (2017). Penggunaan Gypsum Dan Magnesium Sulfat Sebagai Upaya Menurunkan Nilai Resistansi Pentanahan. Jurnal Surya Energy Vol. 2 No. 1, September 2017

[8] Dedi, L.P( 2013). Studi Pemanfaatan Arang Tempurung Kelapa Untuk Perbaikan Resistansi Pembumian Jenis Elektroda Batang . Skripsi. Universitas Brawijaya

[9] Deni, Setiawan (2018). Analisis Pengaruh Penambahan Garam Dan Arang Sebagai Soil Treatment Dalam Menurunkan Resistansi Pentanahan Variasi Kedalaman Elektroda . TRANSIENT, VOL. 7, NO. 2, JUNI 2018.

[10] Ume, Opragen (2015). Studi Pemanfaatan Arang Tempurung Untuk Menurunkan Resistansi Pentanahan Dengan Menggunakan Elektroda Batang Dan Plat. Tugas Akhir. Politeknik Negeri Manado. 